\title{
Telework as a Labor Satisfaction Strategy. Findings in Emerging Economies
}

\author{
Maria del Carmen Gutierrez-Diez, PhD \\ Alma Lilia Sapien Aguilar, PhD \\ Laura Cristina Pinon Howlet, PhD
}

Universidad Autónoma de Chihuahua, México

Doi:10.19044/esj.2018.v14n22p1 ～URL:http://dx.doi.org/10.19044/esj.2018.v14n22p1

\begin{abstract}
Satisfaction and flexibility at work are fundamental for new generations. Telework is conceptualized as a modality that allows the employee to work from a place other than the traditional office, usually from home, making use of Information and Communication Technologies (ICT). This research seeks to relate job satisfaction and teleworking. After a literature review, a survey was designed and sent to Mexican teleworkers. It was found that although there is a clear relationship between job satisfaction and use of telework modality among these employees, there are still issues to resolve among them. Findings show that it is difficult for workers to obtain a balance between time and space devoted to work while they are at home, and the most complicated activity seems to be finding time to do exercise.
\end{abstract}

Keywords: Information and communication technologies, job satisfaction, Mexico

\section{Introduction}

Nowadays, teleworking has been favored by in different ways by various countries in the world, to the point that it has been legislated as a common way of performing work activities. However, it is difficult to implement teleworking, particularly in emerging economies like Mexico. This is due to the fact that changes are required in the organizational culture of companies, as well as in the legal labor framework, because current regulations fail to clearly define all aspects related to teleworking. There is a raise of awareness among human resources areas, related to the implementation of this new way of performing activities. After all, it benefits organizations as well as employees. Teleworking is demanded by employees because of their need for work flexibility, as a way to reconciliate work with personal life. Teleworking is defined as the use of new technologies to work 
outside the employer's premises, which allows the employee to perform tasks outside the office, either at home or elsewhere (Rodríguez, 2007; Rodríguez, Flores \& Ríos, 2012; International Labor Organization [ILO], 2016).

According to a study by a US consultancy from IDC, by $2015,37.2 \%$ of the world's population will be teleworkers. It also points out that the countries that are going to excel in this type of work will be concentrated in China and India, and will develop strongly in the United States and Europe (Universia España, 2013).

Approximately $20 \%$ of workers around the world spend part of the week, working from home, according by Herrera (2013). In 2012, Global Work Place Analytics (2013) showed that $2.6 \%$ of employees in the United States telecommuted. That amounts to approximately 3.3 million people, not including independent workers. According to estimates, in Mexico $58 \%$ of employees telecommute at least once a week and $6 \%$ telecommute full time (Herrera, 2013).

According to a synthesis of studies on teleworking, some major companies report that teleworkers are 35\% - 40\% more productive. It also substantially reduces unscheduled absences by an average of $63 \%$ (ILO, 2013).

It is then that teleworking emerges as an alternative to office space saturation, providing a decrease in fixed costs to companies, and increased productivity, efficiency, and work quality. In the socio-economic aspect, traffic is diminished due to a decrease in transfers from home to the company, helping reduce air pollution due to vehicle emissions. It also offers new employment opportunities for people with disabilities, allowing them to work from home, among other benefits. Additionally, in the current context where new generations of workers seek greater flexibility in the performance of their work activities, this option allows organizations to collaborate in the fulfillment of this type of work aspirations from their younger employees.

Most studies provide only a partial picture of the prevalence of telework, and even then, only for a few developed countries. None of the consulted studies included Mexico into this modality of work; only a couple of reports from ILO and the Organisation for Economic Co-operation and Development (OECD, 2013) talk about Latin America. This paper aims to give a glimpse of the situation in this country, therefore suffers from said limitations. This analysis is only indicative of the general situation of telework, but it still provides a useful indication regarding the state of telework, particularly in Mexico, as an overall trend gradually proliferating.

All of the above highlights the importance of studying the different aspects related to this type of work at a distance. Therefore, the objective of this paper is to identify the level of job satisfaction that affects teleworkers, particularly among ICT workers in Mexico, under the assumption that this work modality 
has a positive impact on employees' job satisfaction, which will result in permanence in the organization.

\section{Background}

Currently, labor flexibility is used as a staff retention strategy, as well as a way to increase productivity. According to several authors (Sánchez- Vidal, Cegarra-Leiva; Cegarra- Navarro, 2011) labor flexibility favors a personal balance, generating performance and satisfaction in the employees. Usually, employees show exhaustion and fatigue when they have constant long hours, insufficient breaks, and shifts that end late. When the worker has time to be with his or her family and friends, as well as to rest properly, he or she manifests a greater satisfaction towards the work schedule. On the contrary, when the time dedicated to personal activities is limited, this negatively influences the employee, his or her attitude towards work, and family unit (ILO, 2002; ILO, 2006; Montesano, 2011). By having labor flexibility policies towards its employees, the company helps reduce boredom, fatigue and stress caused by the clash between work and personal life (Barney \& Elias, 2010).

To achieve this flexibility, it is necessary for the organization to adapt and generate policies that allow achieving the desired balance between personal and work activities. The above will be reflected in a healthy organizational climate (Universia Mexico, 2013a). At the moment, seven out of ten workers think that their company lacks such policies that reconcile the work-family relationship (Universia Mexico, 2013b) and do not dare request it due to lack of support from their bosses and concern for their career development within the organization.

According to a global study by Regus (2011), labor flexibility is often practiced around the world with benefits such as being able to choose where and when to work. This allows to reduce fixed costs, motivates staff, increases company performance, and helps retain human talent by achieving an equilibrium between the employee's personal and work activities. Companies are increasingly aware of all these advantages, but nevertheless, there are few that put it into practice, mainly due to distrust and resistance to change. Data from certain studies (Regus, 2011; World at Work, 2011) show: 81\% of companies offer telecommuting options to their employees (where and when to work); $60 \%$ of global companies believe that it is more feasible to offer these flexibility options for traditional office jobs; $70 \%$ of companies that have these policies, point out that these practices help improve motivation and satisfaction of their employees; $21 \%$ of these companies perceive that this labor flexibility allows to attract and retain human talent. Also, flexibility policies allow companies to reduce their office space, which leads to a $30 \%$ saving on operating costs. 
According to Regus (2011), in Mexico 53\% of companies indicate that only experienced professionals can benefit from work flexibility practices, compared to $40 \%$ worldwide. Similarly, $57 \%$ of organizations say that labor flexibility is more profitable than a traditional work office. There are studies which indicate that teleworking is positively related to production when the tasks to be performed are not boring and related to knowledge. On contrary situations, they relationship is a negative one (Dutcher, 2012).

Today, more and more employees are choosing to use flexible working formats, making use of the technologies at their disposal to do so. This allows workers to have meetings from different locations and schedules, thus reconciling personal activities. However, it is necessary to maintain a balance with regard to face-to-face meetings and distance work (Coenen, Alexander \& Kok, 2013).

\section{Telework}

As cited by ILO (2016), this concept has been around since the early 1970s, when Jack M. Nilles first coined the term ${ }^{1}$. Even now, there is no consensus regarding its exact definition. Different people use the concept in different ways, linking it to a wide range of work arrangements, including mobile work, work in any location outside the usually accepted work premises of the employer, work at a shared office centre or hub, and home-based work. Others apply the term to any distributed forms of ICT-enabled work, such as those in emerging activities related to the growing financial technology industry (known as FinTech) which fuses new ICT and financial services. Telework is also referred as "telecommuting", "work from home", "e-work", "virtual work", "remote work", "distance working", "distributed work", "workshifting" or "flexible working". These terms describe underlying practices whose characteristics overlap but are less synonymous than assumed. Analysts such as Messenger and Gschwind (2016), propose their own telework framework spanning into three generations. By highlighthing flexible "cloudbased" work accessible from anywhere in the world through smartphones and tablets, "telework" as originally understood sounds outdated, as it is associated with old fashioned technologies, like stationary computers, fixed telephones and fax machines; nothing like today's devices used by "digital nomads". Craipeau's (2010) describes telework as undergoing an "evolutionary" process in which such varied ICTs and the greater dispersion

${ }^{1}$ The official story of the "telework" phenomenon began in 1973 when rocket scientist Jack M. Nilles and his interdisciplinary team at the University of Southern California (USC) received a grant from the United States National Science Foundation to investigate "Development of (Public) Policy on the Telecommunications-Transport Tradeoff". He later coined the words "telecommuting" and "telework" as a more concise substitute for the project title. 
of Internet access virtualized work and made it accessible on smaller and more powerful devices like smartphones and tablets.

Work at a distance is a non-traditional way to work. It is a new way of organizing work that allows a flexible schedule for employees and lower costs for companies. In this modality, the employee develops his work activities outside the company, relying on ICT. It can be done full time or part time. According to Cívit and March (2002), it can fall within certain modalities:

1. From the employee's home: it can be full-time or part-time, complementing the time in the company.

2. Telecentres or centers shared by several companies: they give service to employees who live near the centers to avoid long transfers. helped by ICT.

3. Mobile: people who work anywhere, as if it were their workplace,

4. Outsourcing: a company that hires the services of third parties outside its organization, who can perform its functions remotely.

All these modalities present advantages and disadvantages for employees. Positive effects of teleworking include: reduction of travel times from home to work; an increase in autonomy in terms work time, which allows greater flexibility when it comes to organizing working time; improvement in reconciliating work and personal life in general, as well as an increase in productivity. Companies benefit from the improvement of conciliation, which can lead to an increase in motivation and a reduction in staff turnover in the company, increasing productivity and efficiency, while at the same time reducing the need for office space and its associated costs. The disadvantages of teleworking include: tendency to work more hours, overlap between paid work and personal life (work-house interference) and as consequence, the intensification of work. In addition, there are potential benefits or promises of telework for society: it is environmentally friendly, reduces infrastructure stress, global collaboration, improved disaster preparedness, and is better for employees with disabilities (Kurland \& Bailey, 1999; ILO, 2016; ILO, 2017).

For this study, the definition of teleworking is: a flexible way of organizing work, where the employee carries out work activities in a place outside the traditional site, mostly their home, supported by ICT. This modality can be full-time or part-time and is evaluated by the results obtained or the work done. As a rule, sectors whose work involves very high informational components are the most telework-compatible, as information is susceptible to digitization which, in turn, makes it possible to perform jobs remotely (ILO, 2016).

In particular, it is observed that this work modality, being fundamentally supported by ICT, is appropriate for workers in this sector. For this reason, the perception regarding job satisfaction of ICT workers who work under this form of teleworking, was considered relevant for study. 


\section{Methodology}

The research was conducted in Chihuahua, México, according to a quantitative, comparative-descriptive approach. A survey was developed with the objetive of validating the relation between work satisfaction and employees working under any of the teleworking variations (full time, mostly from home, or part time). This instrument was developed using a Likert scale between 1 and 5, to evaluate the level of job satisfaction, where: 1= Very disagreeable; $2=$ Disagree; $3=$ Neutral; $4=$ Agree; $5=$ Very agreeable. The survey reached ICT teleworkers living and working in Mexico, between November and December 2014.

The survey evaluated the dependent variable of Work Satisfaction, from the independent variables related to the dimensions of:

1. Flexible work schedule, which includes selecting your own schedule to perform different activities such as meals, rest and exercise.

2. Reconciliate family and work life, considering: the opportunity to work from home; the balance between work, personal and domestic activities; respect for the spaces and times dedicated to work at home, and even if teleworking is an invasion of the private lives of workers.

Along with general socio-demographic and laboral data, this survey allowed to obtain perceptions of teleworker's job satisfaction as averages to the answers expressed in the scale. According to the scale established, higher values expressed a better perception of job satisfaction by teleworkers.

\section{Analysis and Discussion of Results:}

As explained above, the data gathered allowed to describe different dimensions of the ICT teleworkers. Below are the descriptions of main findings:

Socio-demographic:

- $51.5 \%$ of the respondents were software developers.

- $80 \%$ man, $20 \%$ women.

- $\quad 48.6 \%$ single, $51.4 \%$ married.

- All ages were between 19 and 49. Those between 26 and 35 years old comprised $74 \%$ of the sample, while the remaining $26 \%$ belonged to the 36 to 49 years old range.

- $66 \%$ with no children (childless). For $34 \%$ with children, the ages range from three up to 12 years of age.

Labor:

- Seniority between 6 months and 5 years.

- $80 \%$ salaried workers.

Job satisfaction is analyzed by age groups and teleworking modalities, with the objective of obtaining a better perspective regarding the perceptions 
of different generations of workers, as well as the variations of telework that might offer greater satisfaction to the workers who perform them.

For the first analysis, describing Job Satisfaction in relation to a flexible schedule by Age group, the data obtained is showed in Table 1, as follows:

Table 1. Job Satisfaction in relation to flexible schedules by Age group.

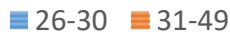

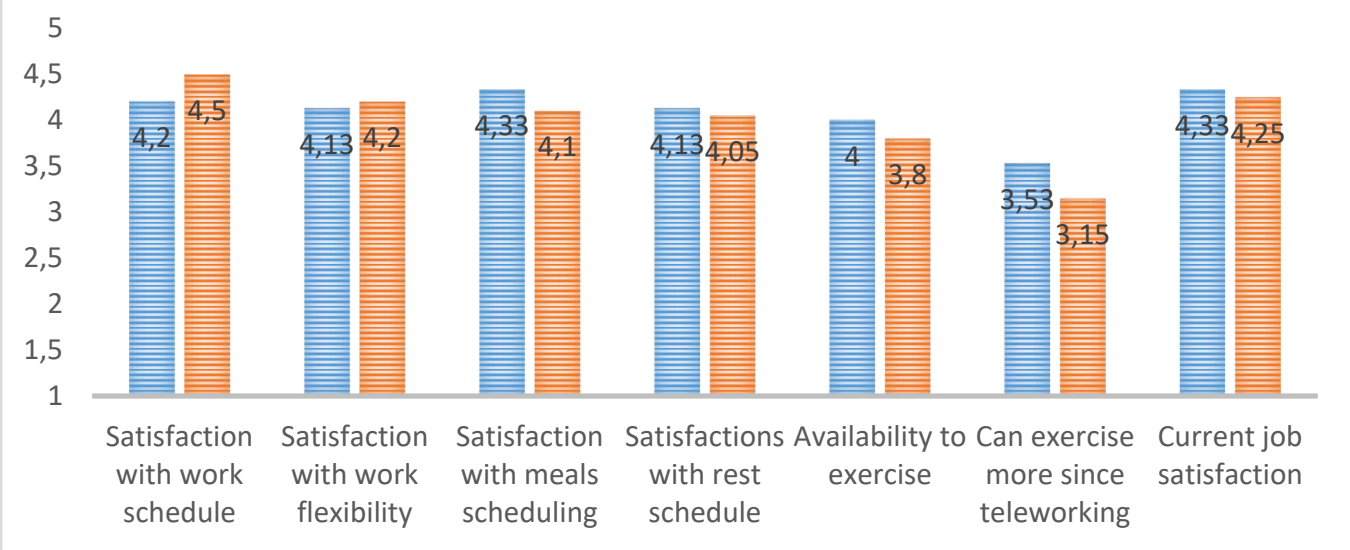

In general, Table 1 shows similar values for both age groups of teleworkers. However, it is observed that in five of the seven evaluated aspects, the greatest satisfaction was found among younger workers. Altough, it is observed that older workers prefer a flexible schedule, in general terms, they have some problems related to the scheduling of meals and rest. But for both groups, the real trouble is finding time to exercise. The overall satisfaction values are above 4 , which indicates a high degree of satisfaction related to flexible schedules.

Table 2 shows the different perceptions when it comes to aspects related to how to reconcile family activities with work done from home.

Table 2. Job Satisfaction when it comes to reconciliation of work and family life by Age group.

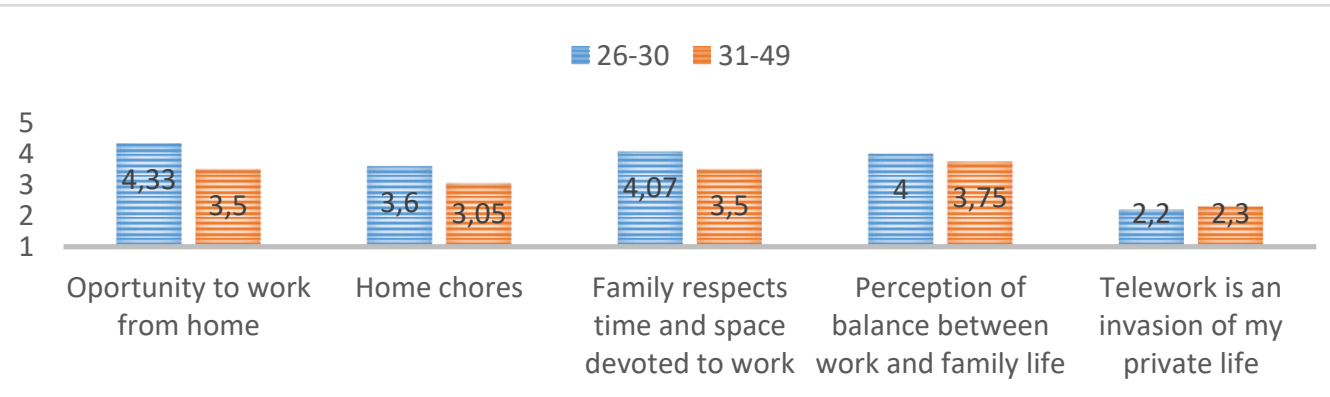


As in the previous table, the younger Age groups have higher values, between 4 and 4.33, when it comes to most of the issues related to this dimension. Meanwhile, older Age groups have close values, but slightly below, The evaluations' averages for them range from 3.05 up to 3.75 . In accordance with the scale interpretation, this means that they generally agree and are satisfied with most of these aspects. Only the "opportunity to work from home" groups show the biggest gap. It is clear how younger employees consider this option more important, when compared to their older counterparts. It is relevant to mention the big difference between the first four questions and the last one, when it comes to the perception regarding invasion of their private life. There is a slight difference between both groups, but in both cases it shows that they do not agree with the statement presented in the completed survey; they do not see telework as an invasion of their private lives. This was the lowest value obtained in all the responses from the survey.

The next table depicts the comparison between Job Satisfaction associated with a flexible schedule, separated by different telework modalities: full time,mostly from home and part time.

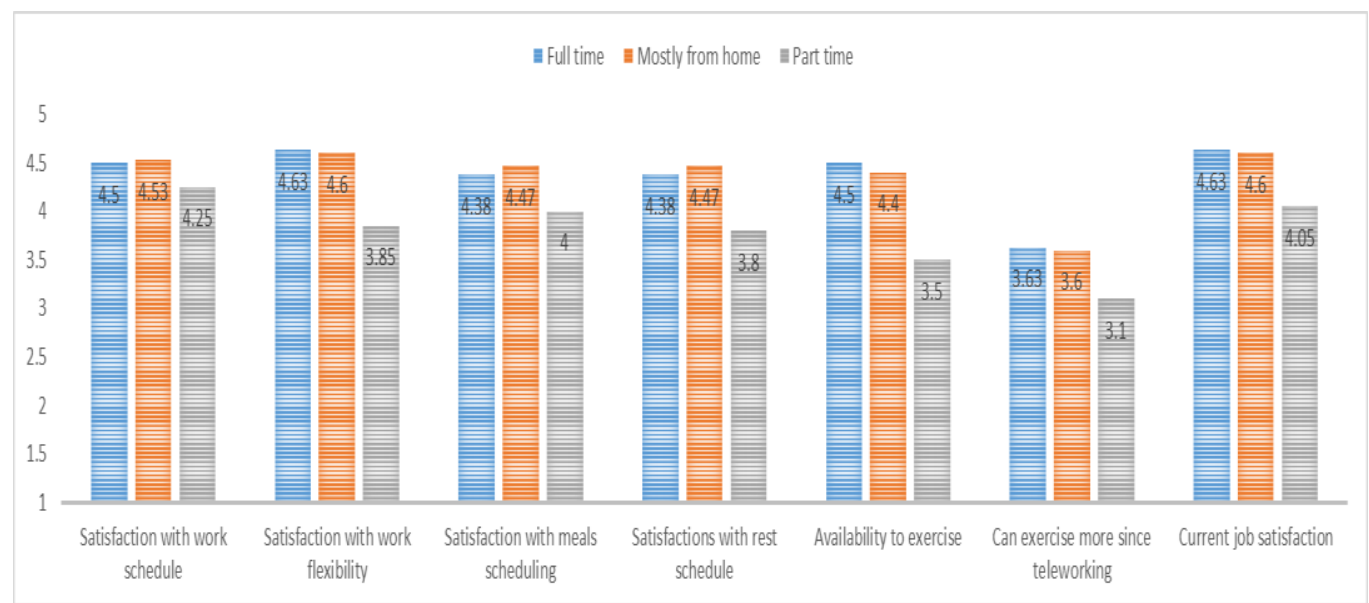

Table 3. Job Satisfaction related with flexible schedules by telework modality.

It is interesting to observe in Table 3, as in all the comparatives, that the group with the lowest level of satisfaction is the one that only works part time in this telework modality. Being that most of the averages are above 4 , in the case of this group, they can be seen as being below this value (3.75). This could indicate that this modality is not so satisfactory in general terms, compared with full time or mainly from home. This shows a relevant opportunity area for this group of employees.

The next table shows the same groups, but with their evaluations' average regarding reconciliation between work and family life. 
Table 4. Job Satisfaction related to reconciliation of work and family life by telework modality.

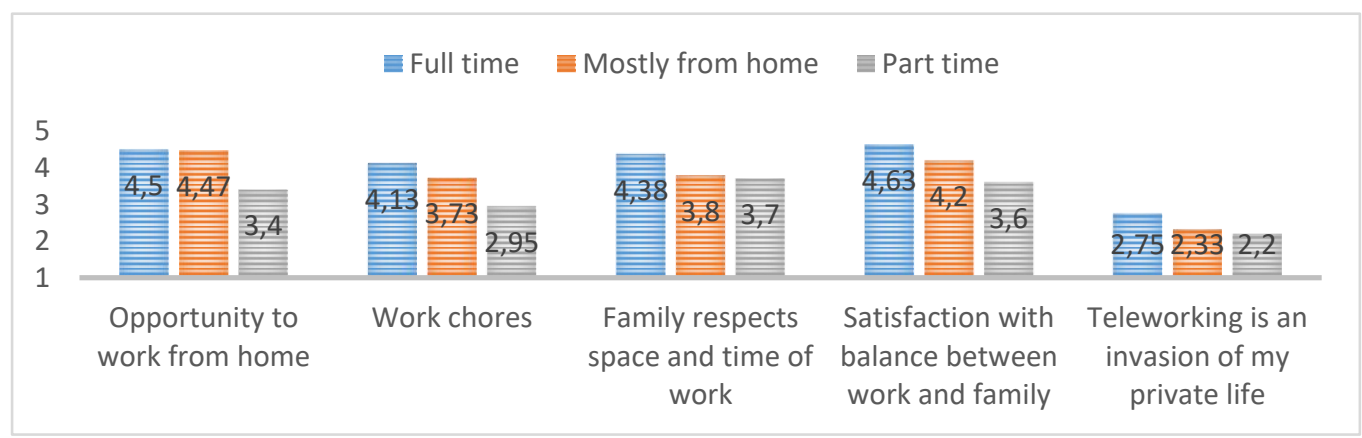

This analysis shows the same tendency as the previous one, where the group that evaluates with lower values their different perceptions associated with this dimension, is the group that works only part time. Likewise, regarding the perception of invasion of privacy, the lowest values of the evaluation continue to appear, which denotes disagreement with respect to the statement presented in the survey.

It is interesting to note that the majority of the respondents are in the age range between 26 and 35 years, which places them in the generation of "digital nomads" who are used to perform multiple activities connected online from any location that allows for it. So, teleworking for them can be said to come naturally. On the other hand, in the current work environments, supervisors belong to older generations, who distrust the activities carried out online and thus out of their sight and control. The need to establish a trust environment between employers and employees becomes clear. It becomes essential in order to be able to perform this type of work in any of its modalities.

\section{Conclusion}

The results obtained show concordance with the studies presented as the background of this analysis. It is clear that the establishment of policies that allow flexibility in the management of the worker's schedule, increases job satisfaction.

This satisfaction entails benefits for the organization that implements these modalities of telework, but at the same time, it confronts the teleworker. It forces him or her to develop a work self-discipline that that would allow him or her to carry out work from another site outside of the traditional office. There are several difficult aspects to face:

1. Having time to exercise seems to be an obstacle for all teleworkers, and if this situation is compounded by the fact that it is usually a sedentary type of work, health self-care becomes a relevant issue for these employees. 
2. The different domestic tasks and the respect that the family itself shows towards the time and space that the teleworker dedicates to his or her work is fundamental for this way of working to be successful.

One aspect that stands out in these results is the clarity with which teleworkers in the ICT sector do not believe that this modality implies an invasion of their personal life. Maybe this aspect can be seen from another perspective in teleworkers working in other sectors. Some employees may worry about being isolated or that their career advancement will be jeopardized, However, with the wide variety of technological innovations available to companies combined with occasional face-to-face contact and performance-based measurement systems, the case for teleworking is a strong one.

The trend for teleworking can be clearly seen and comes along with the need for employers to implement these kind of policies in order to face the challenges of this fast pacing era, particularly when it comes to the retention of talent among young generations, heavily interested in achieving this flexibility and balance between their personal and work activities. Employees working from, or mostly from home, also need to be self-directed. It is necessary to have a defined home office space and they must understand that teleworking is not a substitute for child-care, although it does help working parents meet their family responsibilities. Working time needs to be scheduled around the needs of the new challenges faced by these new familes. (ILO, 2013).

Most under-30s have grown up in a technology-based world of social media, laptops and wireless; they expect to be able to work in more flexible and mobile ways. They often view traditional working practices as outdated and incompatible with their personal aspirations.

As a general conclusion, it can be expressed that job satisfaction achieved through teleworking, shows a level at which the work factors agree with the needs of employees. Teleworking is an option for flexibility, where employees work from home without the need to go to the office, and rely on ICT to carry out their work and be in contact with the organization. Teleworking has advantages and disadvantages that must be taken into consideration for its correct implementation.

Work flexibility, achieved through telework, is being adopted in different parts of the world since it offers benefits to the employee. However, many of the companies from different countries do not favor this type of work due to fear of change and distrust. In order to avoid this situation, the teleworker must show appropriate personal habits in relation to time management in an effective way, which will be reflected in work performance and productivity in the organization. If the employee is not capable of reconciliating his or her family life with work, a feeling of dissatisfaction will eventually grow and will 
be reflected in his attitude towards work, eventually leading to the abandonment of it, or resulting in a poor job performance, at least.

As final remarks and suggestions it is important to note the need to build a common definition of the telework concept. With far-reaching implications for the world of work, it calls for the continued analysis of its effects in different contexts. The future of work could be a mix of blessings and curses, as it allows the individual to spent more time at home, but also work more time from home.

\section{References:}

1. Barney, C. \& Elias, S. (2010) "Flex-time as a moderator of the job stress-work motivation relationship: A three nation investigation", Personnel Review, Vol. 39 Issue: 4 (pp.487502). https://doi.org/10.1108/00483481011045434

2. Cívít, C. \& March, M. (2000). Implantación del Teletrabajo en la Empresa. España: Ediciones Gestión 2000, S.A.

3. Coenen, C., Alexander, K., \& Kok, H. (2013) "Facility management value dimensions from a demand perspective", Journal of Facilities Management, Vol. 11 Issue: 4 (pp.339353). https://doi.org/10.1108/JFM-10-2012-0049

4. Craipeau, S. (2010). Télétravail : le travail fluide. Quaderni, 71,(1), 107-120. https://www.cairn.info/revue-quaderni-2010-1-page107.htm.

5. Dutcher, G. (2012). The effects of telecommuting on productivity: An experimental examination. The role of dull and creative tasks. Journal of Economic Behavior \& Organization, Volume 84, Issue 1 (pp 355363). https://doi.org/10.1016/j.jebo.2012.04.009.

6. Global Workplace Analytics. (Septiembre de 2013). Global Workplace Analytics. Recovered from

7. www.Globalworkplaceanalytics.com/telecommuting-Stadistics

8. Herrera, C. (2013). En América Latina, el promedio de teletrabajo supera a Europa y Estados Unidos. Pulsosocial .

9. International Labor Organization, ILO. (2002). La evolución del empleo, el tiempo del trabajo y la formación en la industria minera. Suiza: Ginebra.

10. International Labor Organization, ILO. (2006). Cambios en el mundo del trabajo. Suiza: Ginebra.

11. International Labor Organization, ILO. (2013). The strong case for working remotely. Retrieved from http://www.ilo.org/global/aboutthe-ilo/newsroom/news/WCMS_208067/lang--en/index.htm

12. International Labor Organization, ILO. (2016). Challenges and Opportunities of Teleworking for Workers and Employers in the ICTS 
and Financial Services Sectors. Retrieved from https://www.ilo.org/wcmsp5/groups/public/---ed_dialogue/--sector/documents/publication/wcms_531111.pdf

13. International Labor Organization, ILO. (2017). Trabajar en cualquier momento y en cualquier lugar: consecuencias en el ámbito laboral Retrieved from http://www.ilo.org/wcmsp5/groups/public/--dgreports/---dcomm/--publ/documents/publication/wcms_544138.pdf

14. Kurland, N.B., \& Bailey, D.E. (1999). "The advantages and challenges of working here, there, anywhere, and anytime", Organizational Dynamics, Vol. 28 (pp. 53-68).

15. Messenger, J. C. and Gschwind, L. (2016), Three generations of Telework: New ICTs and the (R)evolution from Home Office to Virtual Office. New Technology, Work and Employment, 31(pp. 195208) doi:10.1111/ntwe.12073

16. Montesano, M. (2011). Teleworking mum. The essential work from home guide from parents. Australia: Red Bullet.

17. Organisation for Economic Co-operation and Development (OECD), (2013). Perspectivas Económicas De América Latina 2014 Logistica y competitividad para el desarollo. OECD/ CEPAL/ CAF.

18. Regus. (2011). Flexible working goes global. Reporte Global de Flexibilidad Laboral , 1-13. Retrieved from http://annazavaritt.blog.ilsole24ore.com/wpcontent/uploads/sites/54/files/flexible-working-goes-global.pdf

19. Rodríguez, L. A., Flores, J. J., \& Ríos, M. (2012). Proyecto de implementación en modalidad de teletrabajo para personas con discapacidad motora "Teledisc@". Scielo (pp 1-60).

20. Rodríguez, M. (2007). El teletrabajo en el mundo y Colombia. Redalyc Gaceta Laboral , 13 (1) (pp. 29-42).

21. Sánchez- Vidal, M.E, Cegarra-Leiva, D., Cegarra- Navarro, J.G. (2011). ¿Influye el conflicto trabajo-vida personal de los empleados en la empresa? Universia Business Review, núm. 29 (pp. 100-115). Portal Universia S.A. Madrid: España.

22. Universia España. (2013). Teletrabajo: Una modalidad en crecimiento.

23. Universia Mexico. (2013a). Flexibilidad laboral: una tendencia que pisa cada vez más fuerte en las empresas. Universia .

24. Universia Mexico. (2013b). 7 de cada 10 mexicanos desea una mayor flexiblidad laboral. Universia.

25. World at Work, (2011). Turnover Lower for Organizations with an Established Flexibility Culture. Estudio Internacional de flexibildad Laboral. 